\title{
The Use of the Interactive Whiteboard in Mathematics and Mathematics Lessons from the Perspective of Turkish Middle School Students
}

\author{
Nezih Önal ${ }^{1} \&$ Cennet Göloğlu Demir ${ }^{2}$ \\ ${ }^{1}$ Faculty of Education, Niğde Ömer Halisdemir University, Niğde, Turkey \\ ${ }^{2}$ Karabük Science and Arts Center, Karabük, Turkey \\ Correspondence: Nezih Önal, Faculty of Education, Department of CEIT, Niğde Ömer Halisdemir University, 51240, \\ Merkez, Niğde, Turkey
}

Received: May 6, 2017

Accepted: June 19, 2017

Online Published: June 22, 2017

doi:10.5430/ijhe.v6n3p195

URL: https://doi.org/10.5430/ijhe.v6n3p195

\begin{abstract}
It is a great paradox that despite the great importance attached to mathematics education in Turkey, high failure rates are observed among Turkish students in mathematics. For this reason, new applications are implemented in the field of mathematics education in Turkey. One of these applications is the use of technology in mathematics education. Thus, this research aimed to determine the attitudes and opinions of the middle school students towards the use of the interactive whiteboard, which is among the technologies used in mathematics and mathematics lessons. The research is based on a mixed-method research design in which both quantitative and qualitative methods were used. The quantitative part of the study was conducted with 726 students, selected via the convenience sampling method, in 4 different central schools affiliated to the Ministry of Education (MNE) in the Karabük province during the 2015-2016 academic year, while the qualitative part was carried out with 20 participants determined on a voluntary basis. The research data were obtained from the "Attitude Scale towards Mathematics", the "Interactive Whiteboard Attitude Scale" and the semi-structured interviews. It was found that the participants in the survey had a positive attitude towards the use of the interactive whiteboard in mathematics lessons and that they were positively affected by the interactive whiteboard in learning mathematics. In addition, it was concluded that participants' attitudes towards mathematics and the use of the interactive whiteboard was above average. It was also found that the male students' attitudes towards the interactive whiteboard were more positive than that of the female students, and the level of positive attitude towards mathematics decreases as the class level increases accordingly. Finally, a low positive correlation was found between students' attitudes towards mathematics and the interactive whiteboard.
\end{abstract}

Keywords: Middle School, Interactive whiteboard, Mathematics, Attitude, Opinion

\section{Introduction}

\subsection{Integration of Technology and Teaching}

Developing technological tools such as apps, smart phones, social media, tablets, and YouTube have been included in the teaching and learning process over time. The ongoing evolution of technology hardware, software, and instructional applications affect the teaching and learning process (Nadelson, Bennett, Gwilliam, Howlett, Oswalt \& Sand, 2013). In the past, only textbooks were used in the teaching process, which in time continued with the use of computers, projection devices, interactive whiteboards and tablets in order to increase the effectiveness of learning outcomes. Among these products, interactive whiteboards, which can provide enriched learning environments, has started to take place in the classrooms by means of state policies in Turkey since 2010 within the framework of the F@TiH [The Movement of Increasing Opportunities and Improving Technology] Project (The Ministry of Education, 2016).

Technology integration and teaching within the scope of the project is undoubtedly important for every course. However, it can be stated that the use of technology in mathematics, which is a subject that consists of abstract concepts and which a considerable number of students find difficult, has an important place in education (Alakoç, 2003). Moreover, mathematics is regarded to be a difficult and boring lesson, which generally makes students suffer from failure and fear. In other words, students' attitudes towards mathematics are generally negative. The situation has many reasons that can arise from students, teachers, textbooks, learning environments and the passivity of students in the learning process (Çağlar \& Ersoy, 1997). From this point of view, it can be thought that the use of 
technology in the mathematics class can bring about a solution to the mentioned obstacles. For example, Baykul (2001) emphasized that students find mathematics difficult because of its abstract nature and asserted that it should be taught with embody. On the other hand, technology seems to be a good way to embody mathematical concepts. From this aspect, it is possible to say that the tendency to make use of technological products increases. However, this is a hypothesis that needs to be confirmed. For this reason, it is believed that studies conducted by different researchers in the field will make valuable contributions to the related literature.

\subsection{Review of Literature}

A meta analysis study by Cheung \& Slavin (2013) reported that educational technology applications lead to a moderate level of positive effect on mathematics success. Similarly, a meta analysis study by Li \& Ma (2010), which examined the effects of computer technology on mathematics achievement. The authors concluded that computer technology had a moderate level of a positive effect on mathematics achievement and a greater impact on the mathematics achievement of special need students than that of general education students. However even though the effects of technology on mathematics achievement are revealed, the related literature on the use of the interactive whiteboarddoes not provide any clear evidence regarding the merits of this technology in relation to teaching or learning outcomes (Holmes, 2009). However, some of these research studies show that the interactive whiteboard has a positive effect on mathematical success (Ekici, 2008; Kaya, Akçakın \& Bulut, 2013; Miller, Glover \& Averis, 2004; Tezer \& Deniz, 2009). Researchers were interested in not only mathematical success, but also the effect of the interactive whiteboard on students' attitudes and motivation (Mata, Lazar \& Lazar 2016; Şad 2012). The identification of the impact of interactive whiteboards on success will remain limited in determining the role of smart whiteboards in teaching because the affective characteristics possessed by the learners and the factors influencing these characteristics are influential in learning. In this case, emotional perceptions, such as attitude, self-efficacy beliefs, and motivation are encountered as factors affecting education. In the TIMSS-1999 test, it was determined that the level of the self-efficacy belief scores of Turkish students was important for mathematics achievement scores, and the level of self-efficacy beliefs, attitude and value scores of the students were significant for the mathematics achievement scores in the TIMSS-2007 exam (Doğan \& Barıs, 2010). For this reason, revealing attitudes and attitude-related conditions and taking measures based on research results are essential in reaching the target educational goal (Avc1, Coşkuntuncel \& İnand1, 2011). Some research studies reveal that interactive whiteboards enhance attentiveness and motivation of students and, thus, influence their learning positively (Baran, 2010; Lai, 2010; Marzano, 2009; Slay, Sieborger \& Hodgkinson-Williams, 2008). Torff \& Tirotta (2010) reported that the use of interactive whiteboard technology was associated with upper elementary students' motivation in mathematics. Though the effect was very small, students in the treatment group reported higher levels of motivation relative to control students. Similarly, another study reported that the use of an interactive whiteboard in the teaching of mathematics had a positive impact on students' attitude towards mathematics students (Ekici, 2008; Tataroğlu 2009; Yorgancı \& Terzioğlu, 2013). In contrast, he results of the research conducted by Çelik \& Gündüz (2015) show that students do not display positive attitudes towards interactive whiteboards used in mathematics lessons.

\subsection{Purpose}

The success rates in mathematics are quite low in Turkey; hence, research is being conducted on the effect of interactive whiteboards on students' success in mathematics. Thus, despite its high costs, the F@tih Project was initiated by the government. The identification of the relationship between students' attitudes towards the interactive whiteboard and their attitudes towards the mathematics lesson is very important in terms of revealing the psychological process that affects learning. As a matter of fact, a student who does not like the use of a whiteboard can develop negative affective traits over time, or it may be the vice versa; a student who likes to use an interactive whiteboard may begin to become interested in a lesson he does not like over time.

In this research study, students' views and ideas were focused on by emphasizing the importance of student attitudes in the use of interactive whiteboards in teaching mathematics with the aid of educational policies of Turkey where some innovations were introduced. The main research questions of the study are as follows: "What is the attitude of middle school students towards mathematics and the use of the interactive whiteboard? and "Is there a meaningful relationship between middle school students' attitude towards mathematics and the use of the interactive whiteboard? The present study also sought to answer the following sub- research questions:

1-Do middle school students' attitudes towards mathematics and the interactive whiteboard differ significantly by gender?

2-Do middle school students' attitudes towards mathematics and the interactive whiteboard differ significantly by class level? 
3-Do middle school students' attitudes towards mathematics and the interactive whiteboard differ significantly by achievement scores in mathematics?

4-Is there a relationship between the attitudes of middle school students towards mathematics and the use of the interactive whiteboard?

5-What are students' views regarding the influence of the use of interactive whiteboards in mathematics lessons on students' attitudes towards mathematics?

6-What are students' views on the positive and negative aspects of the use of the interactive whiteboard in mathematics lessons?

7-What are students' views regarding mathematics instruction via the use of the interactive whiteboard in mathematics lessons?

\section{Method}

\subsection{Research Model}

In the present research, mixed methods of quantitative and qualitative research methods were used in order to examine the attitudes of middle school students towards mathematics and the use of the interactive whiteboard in lectures.

According to Creswell \& Plano Clark (2011), mixed methods are patterned; they are developed to collect, analyze and correlate both quantitative and qualitative data in a single study or multiple study sequences to understand the research problem. Therefore, a mixed methodology should not be merely defined as a collection of (qualitative and quantitative) data obtained from two different research methods. The basic reason for using a mixed methodology, namely qualitative and quantitative, as the research design is that it enables the research question or problem to be understood more effectively when compared to the use of one of the methodologies. This case can be expressed in the form of strengthening the work to be performed. Nevertheless, it can be concluded that the results obtained from the research of mixed methods are richer, more comprehensive and reliable than the results obtained only from quantitative or qualitative researches. Thus, it is possible to say that a mixed method research, which bears the power of both methods, which makes it a good option to be able to bring different perspectives to the study (Creswell, 2012).

The research is designed in the form of an Explanatory Mixed Method. Because a descriptive survey study was conducted primarily to seek the answers to the research problems, interviews (follow-up interviews) with a select number of participants were conducted to explain the results of the survey study (Creswell, 2012).

In the research, this design was chosen to collect data from a wide range of participants through quantitative research, to be able to generalize the results, and to obtain in-depth information from a select number of participants by means of qualitative research.

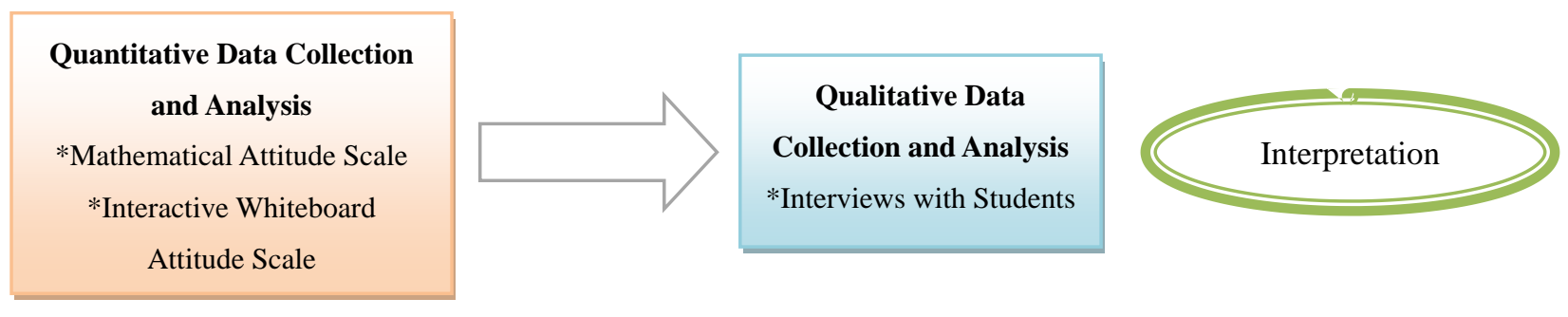

Figure 1. The Explanatory Mixed Methods Design

In the present study, descriptive survey design, which is one of the quantitative research methods, was initially used to reveal the attitudes of middle school students towards mathematics and the use of the interactive whiteboard. Descriptive survey, according to Karasar (2004), is a research approach that aims to describe the past or present as it exists. In this model, the event, individual or object under research is tried to be defined as it appears in its own conditions. In this part of the study, the Mathematical Attitude Scale and the Interactive Whiteboard Attitude Scale were used. The "phenomenology" research method, which is among the qualitative research methods, was used in order that the students' opinions and competences regarding the use of the interactive whiteboard in mathematics courses can be explained in more detail. Phenomenology focuses on the phenomena, the patterns of which we are aware of but not have an in-depth and detailed understanding of. The phenomena can emerge in various forms, such 
as events, experiences, perceptions, orientations, concepts, and situations in the world we live in (Yıldırım \& Şimşek, 2008).

\subsection{Participants}

Quantitative data of the study were collected from 726 middle school students who were educated in 4 different central schools in the Karabük province during the 2015-2016 academic year. The sample group was selected by means of the convenience sampling method. Since 23 of the students were missing or misplaced the data collection tools, they were not included in the research group. Thus, the instruments filled out by 703 students were included in the study for analyses. Some demographic characteristics of the research group are presented in Table 1 below:

Table 1. Characteristics of the Participants

\begin{tabular}{llll}
\hline Variables & & Frequency (N) & Percentage (\%) \\
\hline \multirow{2}{*}{ Gender } & Male & 367 & 52.2 \\
& Female & 336 & 47.8 \\
\hline \multirow{3}{*}{ Grade Level } & 5th Grade & 191 & 27.2 \\
& 6th Grade & 148 & 21.0 \\
& 7th Grade & 173 & 24.6 \\
& 8th Grade & 191 & 27.2 \\
\hline \multirow{3}{*}{ Mathematics Achievement Scores } & $0-45$ & 60 & 8.5 \\
& $46-54$ & 92 & 13.1 \\
& $55-69$ & 138 & 19.6 \\
& $70-84$ & 165 & 23.5 \\
& $85-100$ & 248 & 35.3 \\
\hline
\end{tabular}

When Table 1 is examined, it can be seen that the students who participated in the research are distributed in a balanced manner in terms of gender and class level. It is noteworthy that in terms of the the variable of achievement scores, which are based on the students' report cards, the least number of students $(8.5 \%)$ were present in the group with an achievement score between 0-45, while the highest number of students (35.3\%) were in the group with an achievement score between 85-100.

Table 2. The Characteristics of the Interview Participants

\begin{tabular}{lllc}
\hline Variables & & Participants & Frequency (N) \\
\hline \multirow{2}{*}{ Gender } & Female & S4, S5, S6, S7, S8, S11, S12, S14, S16, S17, S19 & 11 \\
& Male & S1, S2, S3, S9, S10, S13, S15, S18, S20 & 9 \\
\hline \multirow{3}{*}{ Grade Level } & 5th Grade & S1, S2, S3, S4, S5 & 5 \\
& 6th Grade & S6, S7, S8, S9, S10 & 5 \\
& 7th Grade & S11, S12, S13, S14, S15 & 5 \\
& 8th Grade & S16, S17, S18, Ö19, Ö20 & 5 \\
\hline \multirow{3}{*}{ Mathematics Achievement Scores } & $46-54$ & S6, S10, S14 & 3 \\
& $55-69$ & S2, S4, S9, S20 & 4 \\
& $70-84$ & S1, S7, S13, S15, S18, S19 & 6 \\
& $85-100$ & S3, S5, S8, S11, S12, S16, S17 & 7 \\
\hline
\end{tabular}

The qualitative data in the study were collected from 20 participants who were determined on a voluntary basis. The general characteristics of the participants are presented in Table 2. When Table 2 is examined, it can be observed that the gender and grade level of the students that attended the meeting are distributed in a balanced manner. According to the achievement scores variable, it can be observed that the report score was between $46-54$ for 3 students, 
between 55-69 for 4 students, between 70 and 84 for 6 students, and between 85-100 for 7 students with whom interviews were conducted.

\subsection{Data Collection Tools}

\subsubsection{The Mathematics Attitude Scale}

One of the data collection tools used in this research is the Attitude Scale for Mathematics developed by Önal (2013). This scale consists of 22 items and four factors: Interest, anxiety, work and necessity. It was based on a 5-point likert scale: "Strongly Agree", "Agree", "Undecided", "Disagree" and "Strongly Disagree". Inverse coding has been done for the negatively worded items in the scale. The internal consistency coefficient (Cronbach's alpha coefficient) for the whole scale was 90 . The internal consistency coefficient of the four factors were 0.89 for "interest"(item number 10), 0.74 for "anxiety" (item number 5), 0.69 for "study" (item number 4), and 0.70 for "Necessity" (item number 3). The variance explanations of the factors were determined as 35.01\% for Factor 1, 7.71\% for Factor 2, 7.11\% for Factor 3, and $5.31 \%$ for Factor 4 . The total variance explained is $55.12 \%$. Confirmatory factor analysis was also conducted, and it was verified that the scale had a four-factor structure.

\subsubsection{The Interactive Whiteboard Attitude Scale}

Another data collection tool used in the research was the Interactive Whiteboard Attitude Scale, developed by Çelik $\&$ Atak (2012). This scale consists of 24 items and 3 factors. The internal consistency coefficient for this scale was found to be .86. The first factor-Smart Board Easiness (Items 1-11)-includes items related to the facilities of the interactive whiteboard. The second factor - Intelligent Challenges (Items 12-20) involves items related to the challenges of the whiteboard and the last factor -Teacher's Use of Intelligent Board (Items 21-24) contains items related to the interactive use of the teacher's whiteboard. The variance explanations of the factors were $20.83 \%$ for Factor 1, 16.06\% for Factor 2 and $11.07 \%$ for Factor 3. According to the explanatory factor analysis, the total variance of the scale is $47.95 \%$. Confirmatory factor analysis was also performed, and it was verified that the scale had a three-factor structure.

\subsubsection{The Semi-structured Interview Form}

In this study, the researchers conducted semi-structured interviews with 20 participants voluntarily participating in the study. with five students at different grade levels $(5,6,7,8)$ in order to reveal the views of junior high school students about the mathematics learning process and the use of the interactive whiteboard in the lessons. Semi-structured interviews were carried out by preparing specific questions in advance to elicit the same kind of information from the participants through orientation to similar issues (Patton, 2002). In these interviews, the researcher had the flexibility to to ask further questions in addition to the afore-prepared questions in order to get more detailed information about the topics (Yıldırım \& Şimşek, 2008). Following are the questions in the semi-structured interview form prepared by the researchers before the interview:

1. Did the use of the interactive whiteboard in the mathematics courses affect your attitude towards the lesson? How did it affect it? Why do you think like this. Can you explain?

2. While using the interactive whiteboard in your mathematics classes,

a) does it have positive aspects? If so, what are these? Why do you think so?

b) does it have negative aspects? If so, what are these? Why do you think so?

3. Do you think that the use of the interactive whiteboard in mathematics affects your learning? If yes, can you tell me how you are affected by this? Why do you think so?

\subsection{Data Analysis}

The necessary preparations were made before the data were analyzed. In this framework, the scales applied to the participant were checked one by one and the missing and blank ones were eliminated from the analysis process and the numbers were given starting from the remaining forms and then transferred onto SPSS. The Kolmogorov-Smirnov normality test was performed on the data and the homogeneity of variances were also checked. According to the results obtained, the parametric tests to be conducted have been determined. It was decided that $\mathrm{t}$-Tests for two categorical variables and ANOVA for five categorical variables would be performed since the t-test and the ANOVA test assumptions were obtained by taking the average total scores of the scales and the average scores of the scales from the data set transferred onto SPSS. The participants who were interviewed were given code names S1, S2, ... S20 to conceal their names. Subsequently, the interviews were carried out by the researchers and written in alphabetical order into an MS Word text file. The interview transcripts were made in approximately two 
weeks. The researchers performed their analyses based on this file. The interview data were analyzed using the methods of descriptive analysis and content analysis.

\subsection{Validity and Reliability}

To ensure the validity of the quantitative component of the present study, scales whose validity were ensured were utilized. As for the reliability of the study, Cronbach's Alpha coefficient was taken into account. The Alpha coefficient was calculated to be .90 for the mathematics attitude scale and .86 for the interactive whiteboard attitude scale.

The results of the research are discussed in connection with the results of previous research to enhance the reliability of the present study. The most important way of providing internal reliability in research is have the data analyzed by more than one researcher and to check the consistency between the codes. For this reason, the data obtained in order to ensure the internal reliability of the study were analyzed by each researcher.

In the present study, expert opinions were received for the semi-structured interview questions, and the interviews were recorded onto both a voice recorder and on a computer. Attention has been paid to reporting the data collection procedures and the process of reaching the research results in detail. In order to obtain external validity, the research environment has been served by other researchers in a way that allows them to design a different research by following similar paths in terms of participants and the details of the data collection process.

\section{Results}

\subsection{Findings for the First Sub Research Question}

In the study, the descriptive analysis results that reflect the average values of the general attitudes revealed by the implemented scales are as follows:

Table 3. Descriptive Analysis Results Obtained from the Total Scores of the Scales

\begin{tabular}{lcc}
\hline Current Data Count (703) & $\begin{array}{c}\text { Mathematical Attitude Scale } \\
\mathbf{( 2 2} \text { Number) }\end{array}$ & $\begin{array}{c}\text { Interactive Whiteboard } \\
\text { Attitude Scale (24 Number) }\end{array}$ \\
\hline Total Average Scores & 81.60 & 88.24 \\
\hline Minimum & 35.00 & 46.00 \\
\hline Maximum & 110.00 & 120.00 \\
\hline Distortion & -.317 & -.150 \\
\hline Criterion & -.468 & -.491 \\
\hline
\end{tabular}

As it can be seen from Table 3, the mathematics attitude scale $(22 * 5$ Likert $=110)$ yielded a total average score of 81.60 , while the interactive whiteboard attitude scale $(24 * 5$ li Likert $=$ over 120$)$ yielded a total average score of 88.24. These values appear to be above the average. It is also observed that the scales and the kurtosis values of the scale data are between -1 and +1 which indicates a normal distribution of the data.

One of the research questions of the present study was "Do middle school students' attitudes towards mathematics and the use of the interactive whiteboard differ significantly by gender?" The t-test analysis results yielded to this research question are presented below in Table 4:

Table 4. Results of the t-Test Analysis by Gender

\begin{tabular}{lllllll}
\hline & Gender & $\mathbf{N}$ & $\bar{X}$ & $\mathbf{s}$ & sd & t \\
\hline \multirow{2}{*}{ Attitude towards Mathematics } & Female & 367 & 3.6904 & .74017 & \multirow{2}{*}{699.20} & \multirow{2}{*}{.715} \\
& Male & 336 & 3.7296 & .71279 & & \\
\hline Attitude towards the use of the & Female & 367 & 3.5992 & .61775 & \multirow{2}{*}{697.65} & \multirow{2}{*}{3.525} \\
Interactive Whiteboard & Male & 336 & 3.7620 & .60606 & & \\
\hline
\end{tabular}

$* \mathrm{p}<0.05$

When Table 4 is examined, it can be observed that students' attitudes towards math did not show any significant difference by gender $(p=.475)$. However, attitudes towards the interactive whiteboard showed a significant difference in favor of men $(\mathrm{p}=.000)$. In other words, male students were found to have a more positive attitude towards the interactive whiteboard than girls. 


\subsection{Findings for the Second Sub Research Question}

Another research question of the present study was as follows: "Do middle school students' attitudes towards mathematics and the use of the interactive whiteboard differ significantly by class level?" The results of the ANOVA analysis as regards this research question are presented in Table 5 and Table 6 below:

Table 5. Results of the One-way ANOVA by Grade Level

\begin{tabular}{lllllll}
\hline Variables & $\begin{array}{l}\text { Source of } \\
\text { Variance }\end{array}$ & Sum of squares & sd & $\begin{array}{l}\text { Sqaures } \\
\text { Average }\end{array}$ & F & $\begin{array}{l}\text { Difference between } \\
\text { groups }\end{array}$ \\
\hline Mathematical & Between groups & 41.671 & 3 & 13.890 & 29.483 & $5-6 ; 5-7 ; 5-8$ \\
Attitude Scale & Within groups & 329.314 & 699 & .471 & $6-8$ \\
(Grade Level) & Total & 370.985 & 702 & & $7-8$ \\
\hline Interactive & Between groups & 2.120 & 3 & .707 & 1.862 & - \\
Whiteboard & Within groups & 265.251 & 699 & .379 & & \\
Attitude Scale & Total & 267.371 & 702 & & & \\
(Grade Level) & & & & & \\
\hline
\end{tabular}

Table 5 displays the analysis results as to whether there was a significant difference between students' attitudes towards mathematics and interaction with the whiteboard according to the class level variable. The results of the one-way analysis of variance (ANOVA) showed that there was no significant difference between students' attitudes towards mathematics $(\mathrm{p}=.000)$ and attitudes towards interaction with the class $(\mathrm{p}=.135)$. The Tukey's test was conducted to determine which groups the difference had originated from. It was found that there was a significant difference between grade 8 and grades 6 , and 7 . There was also a significant difference between grades 5 , and grades 6,7 and 8 . Table 6 shows the results of the descriptive analysis by class level.

Table 6. Descriptive Analysis Results by Grade Level

\begin{tabular}{llllll}
\hline $\begin{array}{l}\text { Attitude towards } \\
\text { Mathematics }\end{array}$ & N & Min. & Max. & $\bar{Z}$ & SS \\
\hline 5th Grade & 191 & 3.98 & 4.17 & 4.08 & .66 \\
6th Grade & 148 & 3.53 & 3.74 & 3.63 & .64 \\
7th Grade & 173 & 3.57 & 3.78 & 3.68 & .68 \\
8th Grade & 191 & 3.32 & 3.54 & 3.43 & .75 \\
\hline Attitude towards the use of & $\mathbf{N}$ & Min. & Max. & $\bar{X}$ & SS \\
Interactive Whiteboard & & 3.68 & 3.83 & 3.75 & .58 \\
\hline 5th Grade & 191 & 3.60 & 3.80 & 3.70 & .60 \\
6th Grade & 148 & 3.56 & 3.75 & 3.66 & .64 \\
7th Grade & 173 & 3.51 & 3.63 & 3.61 & .64 \\
8th Grade & 191 & &
\end{tabular}

Tables 5 and 6 show that 5 th grade students have a more positive attitude towards mathematics than does 6th, 7th and 8th grade students. Another noteworthy difference is that the attitudes of the 8th grade students towards mathematics are less positive than the students in the other grades.

\subsection{Findings for the Third Sub Research Question}

One other research question of the present study was as follows: "Do middle school students' attitudes to the mathematics and the use of the interactive whiteboard differ significantly by mathematics achievement scores?" The results of the ANOVA analysis performed for this research question are presented in Table 7 and Table 8: 
Table 7. One-way Analysis of Variance (ANOVA) Concerning Analyzed with Scales

\begin{tabular}{|c|c|c|c|c|c|c|}
\hline Variables & $\begin{array}{l}\text { Source of } \\
\text { Variance }\end{array}$ & Sum of squares & sd & $\begin{array}{l}\text { Sqaures } \\
\text { Average }\end{array}$ & $\mathbf{F}$ & $\begin{array}{l}\text { Difference between } \\
\text { groups }\end{array}$ \\
\hline \multirow{3}{*}{$\begin{array}{l}\text { Mathematical } \\
\text { Attitude Scale } \\
\text { (Grade Level) }\end{array}$} & Between Groups & 62.786 & 4 & 15.697 & \multirow[t]{3}{*}{35.549} & \multirow{3}{*}{$\begin{array}{l}0-45--85-100 \\
46-54--70-84 \\
46-54--85-100\end{array}$} \\
\hline & Within Groups & 308.199 & 698 & .442 & & \\
\hline & Total & 370.985 & 702 & & & \\
\hline Interactive & Between Groups & 2.547 & 4 & .637 & \multirow[t]{3}{*}{1.678} & \multirow{3}{*}{-} \\
\hline Whiteboard & Within Groups & 264.823 & 698 & .379 & & \\
\hline $\begin{array}{l}\text { Attitude Scale } \\
\text { (Grade Level) }\end{array}$ & Total & 267.371 & 702 & & & \\
\hline
\end{tabular}

Table 7 presents the results of the analaysis examining whether there is a significant difference between students' attitudes towards mathematics and interaction with the whiteboard. The results of the one-way analysis of variance (ANOVA) showed that there was no significant difference between attitudes towards the interactive whiteboard ( $p$ $=.153$ ) and the students' attitudes towards mathematics according to the achievement scores as reported on the school report card. The Tukey test was conducted to determine which groups the difference originated from. Significant differences were found between those with a score of 85-100 and those with a score of 0-45, 46-54, 55-69, school report grades 70-84 and 46-54. Table 8 shows the results of the descriptive analysis based on students' grades of as reported on their report card:

Table 8. Descriptive Analysis Results of the Math Report Card Score Variable

\begin{tabular}{|c|c|c|c|c|c|}
\hline $\begin{array}{l}\text { Attitude towards } \\
\text { Mathematics }\end{array}$ & $\mathbf{N}$ & Min. & Max. & $\bar{X}$ & SS \\
\hline $0-45$ & 60 & 3.37 & 3.70 & 3.53 & .64 \\
\hline $46-54$ & 92 & 3.25 & 3.51 & 3.38 & .63 \\
\hline $55-69$ & 138 & 3.31 & 3.52 & 3.42 & .65 \\
\hline $70-84$ & 165 & 3.51 & 3.73 & 3.62 & .71 \\
\hline $85-100$ & 248 & 4.02 & 4.18 & 4.09 & .66 \\
\hline $\begin{array}{l}\text { Attitude towards the use of } \\
\text { Interactive Whiteboard }\end{array}$ & $\mathbf{N}$ & Min. & Max. & $\bar{X}$ & SS \\
\hline $0-45$ & 60 & 3.53 & 3.78 & 3.65 & .50 \\
\hline $46-54$ & 92 & 3.52 & 3.76 & 3.64 & .56 \\
\hline $55-69$ & 138 & 3.48 & 3.68 & 3.58 & .61 \\
\hline $70-84$ & 165 & 3.66 & 3.85 & 3.75 & .62 \\
\hline $85-100$ & 248 & 3.62 & 3.78 & 3.70 & .66 \\
\hline
\end{tabular}

As can be seen in Table 7 and Table 8, the students with a score of 85-100 have more positive attitudes towards mathematics than students with scores between 0-45, 46-54, 55-69. Moreover, students with grades 70-84 have more positive attitudes towards mathematics than those with grades 46-54.

\subsection{Findings for the Fourth Sub Research Question}

The fourth research question of the present study was "Is there a relationship between the attitudes of middle school students towards mathematics and their attitudes towards the use of the whiteboard?" A simple linear correlation analysis was performed to seek answers to the mentioned research question. According to the results obtained from this analysis, a significant correlation was found between participants' mathematical and interactive whiteboard attitudes $(\mathrm{r}=.140, \mathrm{p}=.000, \mathrm{p}<0.01)$. 
Table 9. The Relationship Between Attitudes Towards Mathematics and Attitudes Towards Use of Interactive whiteboard

\begin{tabular}{lll}
\hline Variable & $\mathbf{N}$ & $\mathbf{r}$ \\
\hline Attitude towards Mathematics & 703 & .140 \\
Attitude towards the use of the Interactive Whiteboard & & \\
\hline
\end{tabular}

As can be seen from Table 9, there is a low positive correlation between attitude towards mathematics and attitude towards interaction with the whiteboard, $\mathrm{r}=.140, \mathrm{p}<.01$. It is possible to say that the scores of these two attitude scales in the study are weak in relation to each other.

\subsection{Findings for the Fifth Sub Research Question}

The fifth research question of the present study was as follows: When using the interactive whiteboard in mathematics lessons, was your attitude towards the lesson influenced?" The answers to this question by all the 20 students were affirmative: "yes, it affected us positively ". Some of these statements were as follows:

S1: "The interest in interactive mathematics has increased even more because when we do the lecture on the interactive whiteboard, our lesson is very enjoyable."

S7: "I love mathematics more because it makes me interested in using the interactive whiteboard. It increases my interest in math. This board is very interesting. "

S15: "Because of the smooth appearance of this board, and because the shapes are so remarkable, my interest in mathematics has increased greatly."

\subsection{Findings for the Sixth Sub Research Question}

The sixth research question was as follows: "What are your thoughts about the positive and negative aspects of using interactive whiteboard in mathematics lessons?" The answers to this question were coded and the findings are presented in Table 10:

Table 10. Positive and Negative Aspects of Using the Interactive Whiteboard in Mathematics Lessons

\begin{tabular}{|c|c|c|c|}
\hline Theme & Code & Paticipants & $\begin{array}{l}\text { Code } \\
\text { Number }\end{array}$ \\
\hline \multirow{12}{*}{ Positive effects } & Simplifies the lesson & $\mathrm{S} 1, \mathrm{~S} 10$ & 2 \\
\hline & Facilitates comprehension & $\mathrm{S} 1, \mathrm{~S} 7, \mathrm{~S} 8, \mathrm{~S} 10$ & 4 \\
\hline & Increases attention and interest & $\begin{array}{l}\text { S1, S2, S4, S8, S9, S10, S11, S14, } \\
\text { S16, S17, S18, S20 }\end{array}$ & 12 \\
\hline & Facilitates problem-resolution & S4, S7, S13, S16 & 4 \\
\hline & Enables active participation in the course & S2, S8, S9, S10, S17, S19 & 6 \\
\hline & Brings vitality via visuality, color, and shape & S4, S6, S12 & 3 \\
\hline & Saves time & $\mathrm{S} 7, \mathrm{~S} 11, \mathrm{~S} 12, \mathrm{~S} 14, \mathrm{~S} 15$ & 5 \\
\hline & Increases success & $\mathrm{S} 10, \mathrm{~S} 11, \mathrm{~S} 14$ & 3 \\
\hline & Reduces chalk dust & $\mathrm{S} 1, \mathrm{~S} 3, \mathrm{~S} 11$ & 3 \\
\hline & Enables learning to be fun & S2, S3, S4, S8, S11, S12, S14, S20 & 8 \\
\hline & Enables more effective learning & S1, S7, S9, S10, S12, S13, S14 & 7 \\
\hline & Is more convient for the teacher & S3, S6, S14 & 3 \\
\hline \multirow{4}{*}{ Negative effects } & May damage the eye & S3, S4, S5, S13, S14, S20 & 6 \\
\hline & Electricity increases & S3, S9 & 2 \\
\hline & Emits radiation & $\mathrm{S} 4, \mathrm{~S} 9, \mathrm{~S} 10$ & 3 \\
\hline & Hard to see from behind & S4, S11, S13, S19 & 4 \\
\hline
\end{tabular}

It is seen from Table 10 that the opinions of the students are coded under two themes as "positive effects" and "negative effects". It is noteworthy that the use of the interactive whiteboard in lessons has more positive effects than 
negative effects. The most frequent opinions regarding the positive contribution of the interactive whiteboard turned out to be attention, interest, fun, a more effective learning experience, and active participation in the lesson. Some of the participants' views on the positive aspects of the use of the interactive whiteboard in mathematics are as follows:

S7: "Thanks to the interactive whiteboard, we are able to do our lessons and assignments quickly. We understand mathematics better. We also solve the questions easily. "

S12: "The positive aspect of using interactive whiteboards in mathematics teaching is that children become more interested and more passionate towards mathematics."

S14: "We understand mathematics better, which makes mathematics more fun."

S20: "This board is remarkable in appearance, so we pay more attention to the interactive whiteboard. I do not think it has got a negative aspect. "

The most important effect students perceive as an adverse effect of the interactive whiteboard is the concern that the interactive whiteboard may be harmful to the environment. Students are also of the opinion that it is difficult to see the interactive whiteboard from the rear end of the classroom because of its size that it can create headaches due to radiation, and that the electricity cost may be too much for the school. For example, participant S3 said, "all of us shift to a white and bright environment when the internet is opened, and this can also hurt our eyes." Similarly, another participants said, "The interactive whiteboard is harmful for the eyes."

Participants who are eager to use the interactive whiteboard will increase the electricity cost. Participant S9 thinks that "Electric bills will increase due to their work with interactive whiteboards."

"Harmful aspects are that because it is an electronic device, it emits radiation and threatens our health." (S4)

"Problems written on the board can be disturbing to our friends because they can't see clearly from the backseats" (S11)

\subsection{Findings for the Seventh Sub Research Question}

The seventh research question was as follows: "Does the use of interactive whiteboards in your math class affect your mathematics learning? How? "The the answers to this question are presented in Table 11 below:

Table 11. The Effects of the Use of the Interactive Whiteboard in Mathematics Lessons

\begin{tabular}{|c|c|c|c|}
\hline Theme & Code & Participants & $\begin{array}{l}\text { Code } \\
\text { Number }\end{array}$ \\
\hline \multirow{7}{*}{$\begin{array}{l}\text { Impacts of affective } \\
\text { and cognitive skills }\end{array}$} & Interest in the course & $\mathrm{S} 1, \mathrm{~S} 2, \mathrm{~S} 8, \mathrm{~S} 9, \mathrm{~S} 10$ & 5 \\
\hline & Request for the use of whiteboard & S2, S17 & 2 \\
\hline & Permanent learning & S2, S5, S8 & 3 \\
\hline & Problem solving & $\mathrm{S} 1, \mathrm{~S} 2, \mathrm{~S} 3, \mathrm{~S} 5$ & 4 \\
\hline & Effective understanding of the course & S3, S5, S9, S14, S15 & 5 \\
\hline & Opportunity to solve many questions & S8, S13, S14, S15, S17, S19 & 6 \\
\hline & Quick and easy learning & S11, S13, S19 & 3 \\
\hline
\end{tabular}

As can be seen in Table 11, the use of interactive whiteboards in mathematics lessons has had a positive impact on students' affective learning domain by increasing their interest in and desire towards the use of the interactive whiteboard. In addition, students expressed views that referred to cognitive benefits such as persistent learning, problem solving, effective comprehension of the lessons, solving of many questions, and rapid learning.

\section{Discussion and Conclusion}

In this study, the thoughts and the attitudes of middle school students towards mathematics and the use of the interactive whiteboard in mathematics classes and their thoughts were examined. In the current study where an explanatory mixed method was used, attitudes of students were determined by means of scales, and in-depth knowledge about the topic was obtained via semi-structured interview questions and the analysis of the data.

Thus, as a result of the data analyses in the present study, it was first found that the participants' attitudes towards mathematics and the use of the interactive whiteboard was above average. In other words, the attitudes of the students can be considered to be at the level of 'Agree'. This finding indicates that participants liked mathematics and were pleased with the use of the interactive whiteboard in mathematics lessons. This may be due to the fact that 
participants have a high level of motivation towards learning mathematics. As a matter of fact, in the survey conducted by Ocak \& Yamaç (2013), it was stated that the high motivation of the students towards mathematics increased the level of positive attitude towards attitudes. In support of this study, Pamuk, Çakır, Ergun, Yılmaz \& Ayas (2013) stated that students' and teachers' attitudes towards the interactive whiteboard were generally positive.

The present study yielded no significant difference between students' attitudes towards mathematics by gender. This finding is consistent with those reported by other studies examining the relationship between attitudes towards mathematics and gender (Akdemir, 2006; Avc1, Coşkuntuncel \& İnand1, 2011; Işsk \& Çağdaşer, 2009; Kaplan \& Kaplan, 2006; Yılmaz, 2006; Yenilmez \& Özabac1, 2003). However, there are research studies in the related literature that show that there is a significant relationship between attitudes towards gender and mathematics (Duru \& Savaş, 2005; Yetim, 2006). This suggests that there is no consensus in the related literature regarding the relationship between attitude towards mathematics and gender; therefore, it is important that research in this area be continued.

The present study also yielded the finding that 8th grade students had lower positive attitudes towards mathematics than 5th, 6th and 7th grade students, and 5th grade students had a higher level of positive attitude towards mathematics than 6th, 7th, and 8th grade students. Gömleksiz (1997) stated that beginning from elementary class, in mathematics lessons, teachers increasingly focus on encyclopedic knowledge and that they use the methods of lecture, question-and-answer and problem solving (in the form of exercises). Likewise, Baykul (1990) found that highest attitude scores towards the mathematics course belonged to 5th grade students and that the attitude scores decreased as the classes progressed. In the study conducted by Norman (1977), the changes that students go through form grade 2 to their adolescence in their attitude towards mathematics and arithmetic were revealed. According to the research, as the class level increased, the level of positive attitudes of girls and boys towards mathematics decreased. In the study conducted by Koca \& Şen (2005), it was found that the positive attitudes towards mathematics decreased as the class levels of the students increased. The increase in the class level in the research conducted by Taşdemir (2009) reveals that the students who were in the second level of primary education had a lower level of positive attitude towards the mathematics lesson. The decrease in attitude towards mathematics as the class level increases may be due to the fact that mathematics becomes more abstract and becomes more difficult to understand by students as the class level increases.

It was found that students who had high grades of the school report had higher grades of attitude towards mathematics than those with low grades. Indeed, attitude and success are two important components that affect each other (Aiken, 1970; Aşkar \& Erden, 1987). The results of different surveys also show that students' positive attitudes towards mathematics have a positive impact on mathematics success (Caraisco-Alloggiamento, 2008; Yılmaz, 2006).

In the present survey, male students' attitudes towards the interactive whiteboard were more positive than female students. When the attitudes towards the use of the interactive whiteboard were compared by gender in various studies, different findings emerged. Kaya \& Aydin (2011) found that there was a significant difference in favor of men in their research on the views of students in the Social Studies lesson regarding interactive whiteboard applications in the teaching of geography. However, studies have also found that there was no significant difference in attitudes towards the use of the interactive whiteboard among students by gender (Aytaç, 2013; Tataroğlu, 2009; Zengin, Kırılmazkaya \& Keçeci, 2011). However, in this study, it was revealed that the attitude towards interactive whiteboard did not show any significant difference by grade level and report grade. This can be explained by the fact that interactive whiteboards are new to schools. The fact that the school report does not have a significant impact on attitude towards the interactive whiteboard can be considered as an expected result because as a novelty the interactive whiteboard is important for every student's high marks school report.

Another result yielded by the current study was a low positive correlation between students' attitudes towards mathematics and attitudes towards the interactive whiteboard. Other studies in the related literature report that interactive whiteboard use in mathematics teaching affects students' attitudes toward mathematics positively (Ekici, 2008; Tataroğlu 2009; Yorgancı \& Terzioğlu, 2013).

The qualitative data of the current study indicated that students generally reported a favorable opinion on the use of the interactive whiteboard, which were consistent with the findings based on the quantitative data obtained in the study. Participants reported that the use of the interactive board in mathematics classes had "positive" and "negative" effects on mathematics learning. The frequencies obtained by means of coding display more favorable effects than negative effects as regards the use of the interactive whiteboard in mathematics lessons. Students have indicated that the interactive whiteboard enhances attention and interest towards the lesson. In other research studies that have been conducted, similar findings ere revealed - that interactive whiteboards increase the attention and motivation of students and thus they have a positive effect on their learning (Baran, 2010; Lai, 2010; Marzano, 2009; Slay, 
Sieborger \& Hodgkinson-Williams, 2008). From this point of view, it can be said that the use of technology by the teachers in appropriate ways for the purpose of teaching or using the interactive whiteboard has positively affected the students. Studies have found that the use of technology in the lessons is the result of the positive outcome of the attitude towards lectures (Glover, Miller, Averis \& Door, 2007; Hall \& Higgins, 2005; Robinson, 2004; Tercan, 2012; Olgun, 2012; Zengin, Kırılmazkaya \& Keçeci, 2011).

Interactive whiteboards enable students to improve their attitudes towards mathematics in a positive way and to increase their attention and interest. This has made interactive whiteboards highly accessible to all schools. However in order to prevent students from harming their eyes, precautions must be taken in the use of interactive whiteboard software / equipment. Teachers need to be informed about this topic. In addition, the increase in the level of negative attitudes of the students towards mathematics by class level requires the mathematics teaching program to be reconstructed by re-observing the cognitive and affective readiness of the students.

\section{References}

Alakoç Z. (2003). Technological modern teaching approaches in mathematics teaching. The Turkish Online Journal of Educational Technology, 2, 43-49.

Akdemir, Ö. (2006). Elementary students' attitudes towards mathematics lesson and achievement motivation. Unpublished M.A. Thesis, Dokuz Eylül University, İzmir. Retrieved from https://tez.yok.gov.tr/UlusalTezMerkezi.

Aiken L.R. (1970). Attitudes toward mathematics. Review of Educational Research, 40, 551-596. https://doi.org/10.3102/00346543040004551

Aşkar, P. \& Erden, M. (1987). Öğretmenlik mesleğine yönelik tutum ölçeği. Çağdaş Eğitim, 121, 9-11.

Avcı E., Coşkuntuncel, O. \& İnandı Y (2011). Attitudes of twelfth grade students towards mathematics. Mersin University Journal of the Faculty of Education, 7(1), 50-58.

Aytaç, T. (2013). Interactive whiteboard factor in education: Students' points of view and their problems. Academic Journals Educational Research and Reviews, 8(20), 1907-1915. https://doi.org/10.5897/ERR2013.1595

Baran, B (2010). Experiences from the process of designing lessons with interactive whiteboard: Assure as a road map. Contemporary Educational Technology, 1(4), 367-380.

Baykul, Y. (1990). Illkokul beşinci sınıftan lise ve dengi okulların son sinfflarına kadar matematik ve fen derslerine karşı tutumda görülen değişmeler ve öğrenci seçme sinavındaki başarı ile ilişkili olduğu düşünülen bazı faktörler. Ankara: ÖSYM Yayınları.

Baykul, Y. (2001). İlköğretim matematik ögretimi 1-5. sinıflar. Ankara: PegemA Yayıncılık.

Çağlar, M. \& Ersoy Y. (1997). İlköğretim öğrencilerin matematik çalı̧̧ma alışkanlıkları ve öğrenme sorunları. Nasıl Bir Eğitim Sistemi? Güncel Uygulamalar ve Geleceğe İlişkin Öneriler İçinde, (ss. 193-203). İzmir: Bilsa Bilgisayar Yayınları.

Caraisco-Alloggiamento, J.D. (2008). A comparasion of the mathematics achievement, attributes, and attitudues of fourth -, sixth-, and eight-grade students. Dissertation, St. John's University, Newyork.

Cheung, A. C., \& Slavin, R. E. (2013). The effectiveness of educational technology applications for enhancing mathematics achievement in K-12 classrooms: A meta-analysis. Educational Research Review, 9, 88-113. https://doi.org/10.1016/j.edurev.2013.01.001

Creswell, J. W., \& Plano Clark, V. L. (2011). Designing and conducting mixed methods research (2nd ed.). Thousand Oaks, CA: Sage.

Creswell, J. W. (2012). Qualitative inquiry and research design: Choosing among five approaches. CA: Sage.

Çelik, S. \& Atak, H. (2012). The validity and reliability study of interactive whiteboard use. Anadolu Journal of Educational Sciences International, 2(2), 43-60.

Çelik, H. C. \& Gündüz, S. (2015). Examination of Students' attitudes towards the use of smart board in maths classes regarding various factors. Dicle University Journal of Ziya Gökalp Faculty of Education, 25,157-174.

Duru, A. \& Savaş, E. (2005). Gender difference in mathematics teaching, Erzincan University Journal of Education Faculty, 7(1), 35-46.

Doğan, N. \& Barış, F. (2010). Tutum, değer ve özyeterlik değişkenlerinin TIMSS-1999 ve TIMSS-2007 sınavlarında 
öğrencilerin matematik başarılarını yordama düzeyleri. Journal of measurement and Evaluation Education and Psychology 1(1), 44-50.

Ekici, F. (2008). Effects of smart board usage on primary school maths students'success. (Unpublished M.A. Thesis, Marmara University, İstanbul). Retrieved from https://tez.yok.gov.tr/UlusalTezMerkezi

Glover, D., Miller, D., Averis, D., \& Door, V. (2007). The evolution of an effective pedagogy for teachers using the interactive whiteboard in mathematics and modern languages: an empirical analysis from the secondary sector. Learning, Media and Technology, 32(1), 5-20. https://doi.org/10.1080/17439880601141146

Hall, I., \& Higgins, S. (2005). Primary school students' perception of interactive whiteboards. Journal of Computer Assisted Learning, 21(2), 102-117. https://doi.org/10.1111/j.1365-2729.2005.00118.x

Holmes, K. (2009). Planning to teach with digital tools: Introducing the interactive whiteboard to pre-service secondary mathematics teachers. Australasian Journal of Educational Technology, 25(3), 351-365. https://doi.org/10.14742/ajet.1139

Işık, I., \& Çağdaşer, B.T. (2009). The effects of constructivist algebra education on the attitudes toward mathematics of 6th grade students. Kastamonu Education Journal, 17(3), 941-954.

Karasar, N. (2004). Bilimsel araştırma yöntemi (13. Baskı). Ankara: Nobel Yayın Dağıtım.

Kaplan, A., \& Kaplan, N. (2006). Ortaöğretim öğrencilerinin matematik dersine karşı tutumları. Journal of Qafqaz, $17,1-5$.

Kaya, H., \& Aydın, F. (2011). Students' views towards interactive white board applications in the teaching of geography themes in social knowledge lessons. Journal of World of Turks, 3(1), 179-189.

Kaya, G., Akçakın, V., \& Bulut M. (2013). The effects of interactive whiteboards on teaching transformational geometry with dynamic mathematics software. Eighth Congress of European Research in Mathematics Education, Antalya.

Koca, A.Ö. \& Şen, A.İ. (2005). The attitudes of secondary school students towards mathematics and science classes and their reason. Eurasian Journal of Educational Research. 18,186-201.

Lai, H. J. (2010). Secondary school teachers' perceptions of interactive whiteboard training workshops: A case study from Taiwan. Australasian Journal of Educational Technology, 26(4), 511-522. https://doi.org/10.14742/ajet.1069

Li, Q., \& Ma, X. (2010). A meta-analysis of the effects of computer technology on school students' mathematics learning. Educational Psychology Review, 22(3), 215-243. https://doi.org/10.1007/s10648-010-9125-8

Norman, R. (1977). Sex differences in attitudes towards aritmetic-mathematics from early elementary to college levels. Journal of Psycology. 97, 247- 256. https://doi.org/10.1080/00223980.1977.9923970

Marzano, R.J. (2009). Teaching with interactive whiteboards. Educational Leadership, 67(3), 80-82.

Mata, L., Lazar, G., \& Lazar, I. (2016). Effects of study levels on students' attitudes towards interactive whiteboards in higher education. Computers in Human Behavior, 54, 278-289. https://doi.org/10.1016/j.chb.2015.07.044

Miller, D., Glover, D., \& Averis, D. (2004). Motivation: The contribution of interactive whiteboards to teaching and learning in mathematics. http://rcsdk8.edlioschool.com/pdf/technology_committees/iwb/IWB_MOtivation.pdf

Ministry of Education (2016). Fatih Project. http://fatihprojesi.meb.gov.tr/

Nadelson, L., Bennett, D., Gwilliam, E., Howlett, C., Oswalt, S., \& Sand, J. (2013). The intersection of preservice teachers' confidence, perceptions, and ideas for using instructional technology for teaching and learning. International Journal of Higher Education, 2(4), 77-90. https://doi.org/10.5430/ijhe.v2n4p77

Ocak, G. \& Yamaç, A. (2013). Examination of the relationships between fifth graders' self-regulated learning strategies, motivational beliefs, attitudes, and achievement. Educational Sciences: Theory \& Practice, 13(1), 369-387.

Olgun, H. (2012). Investigation of student perceptions of interactive whiteboards in a physics classroom Unpublished M.A. Thesis, Marmara University, İstanbul). Retrieved from https://tez.yok.gov.tr/UlusalTezMerkezi.

Önal, N. (2013). A study on the development of a middle school students' attitudes towards mathematics scale Elementary Education Online, 12(4), 938-948.

Pamuk, S., Çakır, R., Ergun, M., Yılmaz, H.B., \& Ayas, C. (2013). The use of tablet pc and interactive board from 
the perspectives of teachers and students: evaluation of the fatih project. Educational Sciences: Theory \& Practice, 13(3), 1799-1822. https://doi.org/10.12738/estp.2013.3.1734

Patton, M. Q. (2002). Qualitative evaluation and research methods (Third Edition). Thousand Oaks, CA: Sage Publication.

Robinson, M. C. (2004). The impact of the interactive electronic whiteboard on student achievement in middle school mathematics. Master's Thesis, The Florida State University College of Education.

Slay H., Siebörger I., \& Hodgkinson-Williams, C (2008). Interactive whiteboards: Real beauty or just —lipstick? Computers \& Education, 51, 1321-1341. https://doi.org/10.1016/j.compedu.2007.12.006

Taşdemir, C. (2009). Elementary education second level students' attitude to the mathematic lesson: an example for bitlis city. Dicle University Journal of Ziya Gökalp Faculty of Education, 12, 89-96.

Tataroğlu, B. (2009). The effect of utilizing the smart board in mathematics teaching on 10th grade students, their academic standings, their attitude towards mathematics and their self efficacy levels. Unpublished M.A. Thesis, Dokuz Eylül University, İzmir. Retrieved from https://tez.yok.gov.tr/UlusalTezMerkezi.

Tercan, İ. (2012). The effects of interactive whiteboard use on achievement, attitude and motivations on science and technology course of students. Unpublished M.A. Thesis, Necmettin Erbakan University, Konya. Retrieved from https://tez.yok.gov.tr/UlusalTezMerkezi.

Tezer M. \& Deniz A.K. (2009) The effect of using an interactive board in mathematics course on the learning of equation solving. 9th International Educational Technology Conference, Ankara, Turkey.

Torff, B., \& Tirotta, R. (2010). Interactive whiteboards produce small gains in elementary students' self-reported motivation in mathematics. Computers \& Education, 54, 379-383. https://doi.org/10.1016/j.compedu.2009.08.019

Yenilmez, K. \& Özabacı, N. Ş. (2003). Yatılı öğretmen okulu öğrencilerinin matematik ile ilgili tutumları ve matematik kaygı düzeyleri arasındaki ilişki üzerine bir araştırma. Pamukkale University Journal of Education, $14,132-146$.

Yetim, H. (2006). The relationship between secondary school of 8th classroom students's attitudes towards mathematics and Turkish classes and students's achievement level of the classes. Unpublished Ph.D. Thesis. Dokuz Eylül University, İzmir. Retrieved from https://tez.yok.gov.tr/UlusalTezMerkezi.

Yıldırım, A. \& Şimşek, H. (2008). Sosyal bilimlerde nitel araştırma yöntemleri (5. Bask1). Ankara: Seçkin.

Y1lmaz, E. T. (2006). The factors that effect the mathematics achievement of the students of turkey in programme for intemational student assessment (PISA). Unpublished M.A. Thesis, Hacettepe University, Ankara. Retrieved from https://tez.yok.gov.tr/UlusalTezMerkezi.

Yorgancı S. \& Terzioğlu Ö. (2013) The effect of using interactive whiteboard in mathematics instruction on achievement and attitudes toward mathematics. Kastamonu Education Journal, 21(3), 919-930.

Zengin, F. K., Kırılmazkaya, G. \& Keçeci, G. (2011). Elementary students use of smart board the effect of achievement and attitude in science and technology course. 5th International Computer \& Instructional Technologies Symposium, Frrat Universitesi, Elazı̆̆. 